\title{
Efek Antidiabetes Fraksi Etil Asetat Ampas Tahu Pada Model Hewan Resisten Insulin
}

\section{Antidiabetic of Ethyl Acetate Tofu Residue in Insulin Resistant Animal Models}

\author{
Penulis \\ Herlina $\mathbf{N}^{1^{*}}$, Dwi Indriati ${ }^{1}$, Mulyati $^{1}$, Yulianita $^{1}$, Elsa Fitria ${ }^{2}$ \\ Afiliasi \\ ${ }^{1}$ FMIPA, Universitas Pakuan, Jawa Barat, 16144, Indonesia \\ ${ }^{2}$ FMIPA, Universitas Sriwijaya, Sumatera Selatan, 30128, Indonesia
}

\section{Kata Kunci \\ $\rightarrow$ Fraksi Etil Asetat Ampas Tahu \\ $\rightarrow$ resisten insulin \\ $\rightarrow$ diabetes mellitus}

\section{Keywords \\ - Ethyl Acetate Tofu Faction \\ - insulin resistance \\ - diabetes}

$\begin{array}{ll}\text { Diterima } & 13 \text { September } 2019 \\ \text { Direvisi } & 14 \text { April } 2020 \\ \text { Disetujui } & 20 \text { April } 2020\end{array}$

*Penulis Koresponding Herlina N

email:

nina.herlina@unpak.ac.id

\section{ABSTRAK}

Ampas tahu telah menunjukkan efek antidiabetes pada model hewan yang diinduksi aloksan. Penelitian ini bertujuan untuk menguji efek antidiabetes fraksi etil asetat ampas tahu (FEAAT) pada model hewan resisten insulin. Ampas tahu diekstraksi dengan metode refluks menggunakan etanol dan $\mathrm{HCl}$, kemudian difraksinasi menggunakan etil asetat. Mencit dibagi menjadi lima kelompok, yaitu kelompok normal, induksi, obat pembanding (Metformin), FEAAT1 (200 mg/kg bb) dan FEAAT2 (400 mg/kg bb). Mencit diinduksi resisten insulin dengan pemberian diet tinggi lemak dan glukosa selama 14 hari. kemudian diberikan bahan uji selama 14 hari. Pengujian efektivitas antidiabetes dilakukan dengan modifikasi Tes Toleransi Glukosa Oral (TTGO). Nilai Area Under Curve (AUC) diukur sebagai gambaran efek penurunan kadar glukosa darah. Data AUC yang diperoleh dianalisis secara statistik menggunakan uji Analisi of varians (ANOVA) dengan tingkat kepercayaan 95\%. Hasil uji menunjukkan bahwa nilai AUC kelompok FEAAT1 tidak memberikan perbedaan yang nyata $(p>0,05)$ dibandingkan dengan kontrol negatif, sedangkan kelompok FEAAT2 dan Metformin memberikan perbedaan yang nyata $(p<0,05)$. Jika dibandingkan dengan kelompok normal, kelompok FEAAT2 dan Metformin tidak memiliki pengaruh yang berbeda nyata $(p>0,05)$ sementara nilai AUC FEAAT1 berbeda nyata $(p<0,05)$. Dengan demikian dapat disimpulkan bahwa FEAAT2 efektif sebagai antidiabetes pada model hewan resisten insulin.

\section{ABSTRACT}

Tofu residue has shown an antidiabetic effect in alloxan induced diabetic. The aim of this study was to evaluate antidiabetic effect of the ethyl acetate fraction of tofu residue at insulin resistant animal model. Tofu residue was extracted using reflux with the solvent ethanol and $\mathrm{HCl}$, then fractionated using ethyl acetate. Mice were divided into five groups, namely normal, induction, comparative drugs (Metformin), FEAAT1 (200 mg kg b.w.) and FEAAT2 (400 mg/kg b.w.). Mice were induced insulin resistance by giving a diet high in fat and glucose during 14 days, then mice treated with the test material during 14 days. Antidiabetic effect was measured by oral glucose tolerance test modification. Area Under Curve (AUC) represents the rise and subsequent lowering of blood glucose levels. The AUC data obtained were statistically analyzed using the Analysis of Variance (ANOVA) test with confidence level of 95\%. The results showed that the AUC value of the FEAAT1 group have not statistically significant $(p>0.05)$ between the induction group, while the FEAAT2 and Metformin groups have a significantly difference $(p<0.05)$. When compared with the normal group, the FEAAT2 and Metformin groups have not a significantly different effect $(p>0.05)$ while the AUC FEAAT1 value was significantly different $(p<0.05)$. It can be concluded that administration of FEAAT2 for 2 weeks provides effectiveness as an antidiabetic in animal models. 


\section{PENDAHULUAN}

Diabetes Mellitus merupakan gangguan metabolisme kronis dengan multi etiologi yang ditandai dengan hiperglisemia disertai dengan gangguan metabolisme karbohidrat, lipid dan protein sebagai akibat insufisiensi fungsi insulin (Dipiro et al. 2008). Hiperglisemia pada penderita DM tipe 2 lebih sering disebabkan karena terjadinya resistensi insulin pada jaringan perifer, sehingga kebanyakan glukosa gagal dibawa masuk ke dalam sel (hévenod, 2008). Kegemukan atau obesitas merupakan salah satu faktor resiko DM. DM mengancam kehidupan manusia melalui komplikasi diabetes yang serius termasuk retinopati, nefropati dan neuropati otonom (Zimmet et al. 2014 dan Lorber 2014). Saat ini obat anti-diabetes sintetis banyak digunakan dalam pengobatan diabetes tipe 2, tetapi efek samping membatasi penerapan obatobatan (Derosa \& Maffioli 2010). Terapi nutrisi menjadi salah satu pendekatan yang baik untuk membantu pasien diabetes mengontrol kadar glukosa darah (KGD) yang optimal dan mengurangi risiko kerusakan jaringan jangka panjang (ADA 2012).

Indonesia memiliki potensi ampas tahu cukup tinggi, karena produksi kedelai mencapai 779.074 ribu ton pada tahun 2012 (BPS 2012), hal ini berpengaruh pada produksi tahu yang menggunakan bahan baku kedelai. Ampas tahu dianggap sebagai limbah yang tidak bernilai ekonomis sehingga biasanya dibuang tanpa diolah lebih lanjut untuk dijadikan produk bernilai ekonomis. Studi nutrisi yang dilakukan pada hewan dan studi intervensi dengan manusia menunjukkan bahwa konsumsi protein kedelai dengan isoflavon meningkatkan kontrol glukosa dan mengurangi resistensi insulin (Kwon et al.,2009). Menurut Balai Penelitian dan Pengembangan industri tahu di Indonesia sebagian besar masih melakukan pengolahan secara sederhana sehingga kandungan bermanfaat yang terdapat di ampas tahu masih cukup banyak (Arbaiyah 2003). Sulistiani (2004) melaporkan bahwa tepung ampas tahu mengandung protein $(11,04 \%)$, lemak $(19,69 \%)$, karbohidrat $(51,50 \%)$, serat pangan tidak larut $(42,75 \%)$ dan serat pangan larut $(8,75 \%)$.

Jannatun (2009) melaporkan bahwa ampas tahu mengandung isoflavon genistein dan daidzein sebesar $65.93 \mathrm{mg} / 100 \mathrm{~g}$ dan $63.68 \mathrm{mg} / 100 \mathrm{~g}$. Kandungan ini diduga memiliki peranan penting dalam reglukosasi glukosa darah. Bhattamisra et al (2013) dan Babu et al (2013) serta Cheong et al (2014) mengkonfirmasi bahwa isoflavon dari kedelai dapat membantu memperbaiki kondisi hiperglikemia. Akan tetapi belum ada yang mengkonfirmasi efek fraksi etil asetat ampas tahu sebagai antidiabetes pada model hewan resisten insulin. Oleh karena itu dalam penelitian ini dilakukan pengujian efek hipoglikemik pada ampas fraksi etil asetat ampas tahu pada mencit yang diinduksi resisten insulin dengan pemberian emulsi lemak dan glukosa. Dari hasil penelitian ini diharapkan nilai guna ampas tahu semakin meningkat dan komoditas ampas tahu semakin berkembang sehingga meningkatkan pendapatan produsen tahu.

\section{METODE}

\section{Alat dan Bahan}

Alat yang digunakan adalah glukometer (Easy touch, Miaoli County,Taiwan), strip test glukosa (Easy touch, Miaoli County,Taiwan), sonde oral, timbangan. Bahan yang digunakan ampas tahu (Pabrik Tahu Sumedang Bumi Armasta, Bogor, Indonesia), vacuum dryer, etanol $70 \%, \mathrm{HCl} 4 \mathrm{~N}$, etil asetat, kloroform, $\mathrm{NH} 4 \mathrm{OH}, \mathrm{H} 2 \mathrm{SO} 42 \mathrm{M}$, serbuk magnesium, alkohol, akuades, $\mathrm{FeCl} 31 \%$, metanol, pakan (512 Bravo), Metformin, lemak sapi, kolesterol, propiltiourasil, natrium glutamat, sukrosa, fruktosa, tween 80, propilen glikol. Mencit jantan galur deutch democratic Yokohama (DDY) yang berumur sekitar 11 minggu dengan kisaran bobot badan $25 \mathrm{~g} \mathrm{-}$ 30 g sebanyak 30 ekor.

\section{Ekstraksi dan Fraksinasi Ampas Tahu}

Ampas tahu segar dikeringkan menggunakan vacuum dryer hingga diperoleh ampas tahu kering. Setelah itu dilakukan ekstraksi dengan metode refluks. Sampel ampas tahu sebanyak $1 \mathrm{~kg}$ direfluks menggunakan campuran $\mathrm{HCl} 4 \mathrm{~N}$ dan etanol dengan perbandingam 1:8 selama 2 jam pada suhu $70^{\circ} \mathrm{C}$. Campuran disaring dengan menggunakan pompa vakum dan kertas saring Whatman nomor 41. Filtrat yang diperoleh kemudian dipekatkan menggunakan rotavapor. Ekstrak ampas tahu difraksinasi dengan etil asetat (1:1) menggunakan corong pisah. Fraksi etil asetat yang diperoleh kemudian disaring, dan dipekatkan dengan rotavapor.

\section{Uji Mutu dan Uji Fitokimia}

Proses pengujian mutu ampas tahu kering meliputi kadar air, kadar abu dan uji fitokimia. Pengujian kadar air mengacu pada Materia Medika (Depkes 1995), kadar abu mengacu pada Parameter Standar Umum Ekstrak Tumbuhan Obat (Depkes 2000) dan untuk uji fitokimia mengacu pada Harborne (1987). 


\section{Persiapan Hewan}

Mencit diaktimasi dengan kondisi laboratorium selama 7 hari. Mencit diletakkan dalam kandang pada temperatur $25 \pm 2^{\circ} \mathrm{C}$ dengan pencahayaan selama 12 jam dan tanpa pencahayaan selama 12 jam. Semua percobaan telah disetujui (Persetujuan Protokol No.2015006) oleh Komite Etik Penggunaan Hewan Percobaan FMIPA Universitas Pakuan dengan SK No.16/KEPHP-UNPAK/3-2019. Mencit diberikan makanan dan minuman ad libitum selama 1 minggu sebelum induksi model hewan dilaksanakan.

\section{Pembentukan Model Hewan Resisten Insulin}

Induksi diabetes mellitus dengan model resisten insulin dilakukan dengan pemberian emulsi tinggi lemak dan glukosa mengacu pada penelitian Ai et al. (2005). Emulsi ini mengandung lemak sapi (20\%), kolesterol $(5 \%)$, propiltiourasil $(1 \%)$, natrium glutamate $(1 \%)$, sukrosa $(5 \%)$, fruktosa (5\%), tween $80(20 \%)$, propilen glikol (30\%) dan akuades (13\%). Setelah 2 minggu pemberian induktor, kadar glukosa darah diukur menggunakan glukometer (Easy touch, Miaoli County,Taiwan) dengan menggunakan modifikasi tes toleransi glukosa oral.

\section{Pengujian Efek Antidiabetes Fraksi Etil Asetat Ampas Tahu (FEAAT)}

Mencit secara acak dibagi menjadi lima kelompok yaitu kelompok normal (diberikan larutan karboksimetilselulosa natrium (Na CMC) 1\% dengan volume pemberian $1 \mathrm{ml} / 20 \mathrm{~g}$ ), kelompok induksi (diinduksi dan diberikan larutan karboksimetilselulosa natrium ( $\mathrm{Na} \mathrm{CMC}$ ) 1\% dengan volume pemberian $1 \mathrm{ml} / 20 \mathrm{~g}$ ), obat pembanding (Metformin $65 \mathrm{mg} / \mathrm{kgbb}$ ), FEAAT1 $(200 \mathrm{mg} / \mathrm{kg} \mathrm{bb})$ dan FEAAT2 $(400 \mathrm{mg} / \mathrm{kgbb})$.

\section{Pengukuran Glukosa Darah}

Glukosa darah diukur setiap minggu pada mencit selama perlakuan. Sampel darah dikumpulkan dari vena ekor mencit, dan diukur menggunakan glukometer Easy touch sesuai dengan instruksi pabrik. Hasilnya dinyatakan sebagai plasma mg /dL.Pemeriksaan glukosa darah menggunakan modifikasi tes toleransi glukosa. Mencit diberikan sediaan uji. Tiga puluh menit kemudian, seluruh kelompok diberikan larutan glukosa secara oral dengan dosis $2 \mathrm{~g} / \mathrm{kgbb}$. Selanjutnya, setiap 30 menit setelah pemberian glukosa, darah dari tiap hewan disampling untuk ditentukan KGD hingga menit ke-150. Untuk itu, akan didapatkan parameter KGD hewan pada menit ke$0,60,90,120$ dan 150. Dilakukan pula analisa dengan melihat perbandingan luas daerah di bawah kurva.Area di bawah kurva (AUC) dihitung untuk mewakili toleransi glukosa. Nilai disajikan sebagai persentase kadar glukosa plasma awal dengan cara rumus:

Luas Area di bawah kurva ; $\left(\mathrm{KGDt}_{1}+\mathrm{KGDt}_{2}\right) / 2 \times\left(\mathrm{t}_{2}-\mathrm{t}_{1}\right)$

Keterangan :

$K_{G D_{t 1}}$ kadar glukosa darah periode pertama pengukuran $(\mathrm{mg} / \mathrm{dl})$

$\mathrm{KGD}_{\mathrm{t} 2}$ : kadar glukosa darah periode kedua pengukuran $(\mathrm{mg} / \mathrm{dl})$

t1 = Periode pertama pengukuran kadar glukosa darah (menit)

t2 = periode kedua pengukuran kadar glukosa darah (menit)

\section{Analisis Data}

Hasil penelitian dinyatakan sebagai rata-rata \pm SD. Data dianalisis dengan analisis varians satu arah (ANOVA). SPSS versi 25.0 (SPSS Inc., Chicago, IL, USA) digunakan untuk melakukan semua analisis statistik. Nilai $P$ kurang dari $0,05(P<0,05)$ dianggap sebagai indikasi signifikansi.

\section{HASIL DAN PEMBAHASAN}

\section{Kadar Air, Kadar Abu dan Kandungan Fitokimia} Ekstrak Ampas Tahu

Ampas tahu kering mengandung kadar air $10,45 \%$ dan kadar Abu sebesar 10,95\%. Setelah diekstraksi dengan etanol $70 \%$ dan $\mathrm{HCl}$ kadar air ampas tahu $35,37 \%$ dan kadar abu $12,79 \%$ sebagaimana ditunjukkan pada Tabel 1. Ekstrak ampas tahu mengandung flavonoid dan tanin sebagaimana ditunjukkan pada Tabel 2.

Pembentukan model hewan resisten insulin dilakukan dengan pemberian emulsi tingggi lemak dan glukosa selama dua minggu. Hasil induksi ditunjukkan pada Gambar 1. 


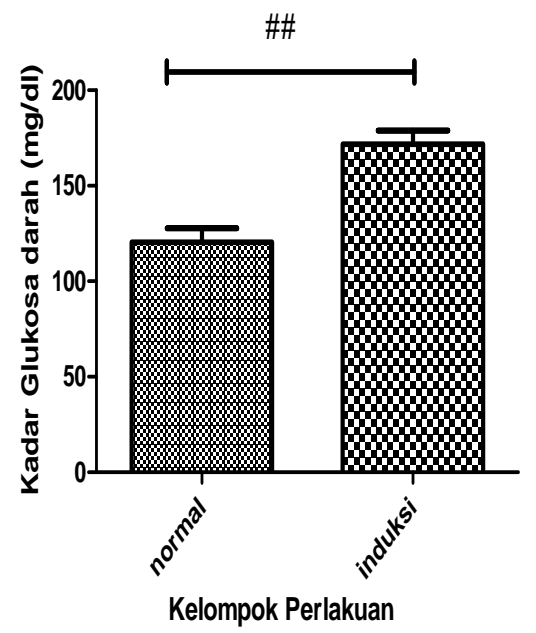

Gambar 1. Hasil induksi Emulsi Tinggi lemak dan Glukosa selama 14 hari perlakuan

Tabel 1. Kadar Air dan Kadar Abu Ampas Tahu

\begin{tabular}{|c|c|c|c|c|}
\hline Uji Karakteristik & Sampel & Hasil & Rata-rata & Standar \\
\hline \multirow{4}{*}{ Kadar Air } & \multirow{2}{*}{ Serbuk kering } & $10,38 \%$ & \multirow{2}{*}{$10,95 \%$} & \multirow{4}{*}{$\leq 10 \%$} \\
\hline & & $11,53 \%$ & & \\
\hline & \multirow{2}{*}{ Ekstrak etanol } & $34,58 \%$ & \multirow{2}{*}{$35,37 \%$} & \\
\hline & & $36,17 \%$ & & \\
\hline \multirow{4}{*}{ Kadar Abu } & \multirow{2}{*}{ Serbuk kering } & $1,95 \%$ & \multirow{2}{*}{$10,95 \%$} & \multirow{4}{*}{$\leq 16$} \\
\hline & & $1,93 \%$ & & \\
\hline & \multirow{2}{*}{ Ekstrak etanol } & $13,52 \%$ & \multirow{2}{*}{$12,79 \%$} & \\
\hline & & $12,07 \%$ & & \\
\hline
\end{tabular}

Tabel 2. Hasil uji Fitokimia Ampas Tahu (Harborne, 1987)

\begin{tabular}{|c|c|c|c|}
\hline Senyawa & Pereaksi & Serbuk Ampas Tahu & Ekstrak Etanol Ampas Tahu \\
\hline \multirow{3}{*}{ Alkaloid } & Bouchardat & + & - \\
\hline & Dragendorf & - & - \\
\hline & Meyer & - & - \\
\hline Flavonoid & $\mathrm{HCl} . \mathrm{Mg}$ & + & - \\
\hline Tanin & $\mathrm{FeCl} 33 \%$, gelatin & + & + \\
\hline Saponin & Akuades & - & - \\
\hline
\end{tabular}

Keterangan (+) ; Positif,, (-) ; negatif

Gambar 1 menunjukkan bahwa kadar glukosa darah (KGD) kelompok normal berbeda signifikan $(P<0,001)$ dibandingkan kelompok normal. Hal ini menunjukkan bahwa induksi model hewan resisten insulin dinyatakan berhasil. Model mencit resisten insulin yang digunakan dalam penelitian ini meniru resistensi insulin dan hiperglikemia pada pasien DMT2 (Srinivasan et al. 2005 dan Reed et al. 2000). Makanan tinggi lemak dan glukosa ini mengandung lemak sapi, kolesterol, propiltiourasil (PTU), sukrosa, dan fruktosa yang diberikan secara oral untuk memastikan hewan mendapatkan asupan lemak dan glukosa yang sama untuk mencapai kondisit resisten insulin. Makanan ini didesain sama seperti kondisi yang sesuai dengan keadaan nyata dimana manusia lebih tertarik memakan makanan siap saji yang mengandung tinggi lemak dan glukosa. Lemak jenuh dan kolesterol dapat meningkatkan kadar lipid dengan cepat untuk pembentukan resistensi insulin, fruktosa memberikan suplai karbon bagi gliserol untuk membentuk trigiserida serta mendorong terjadinya lipogenesis sehingga meningkatkan penyimpanan lemak. PTU bekerja 


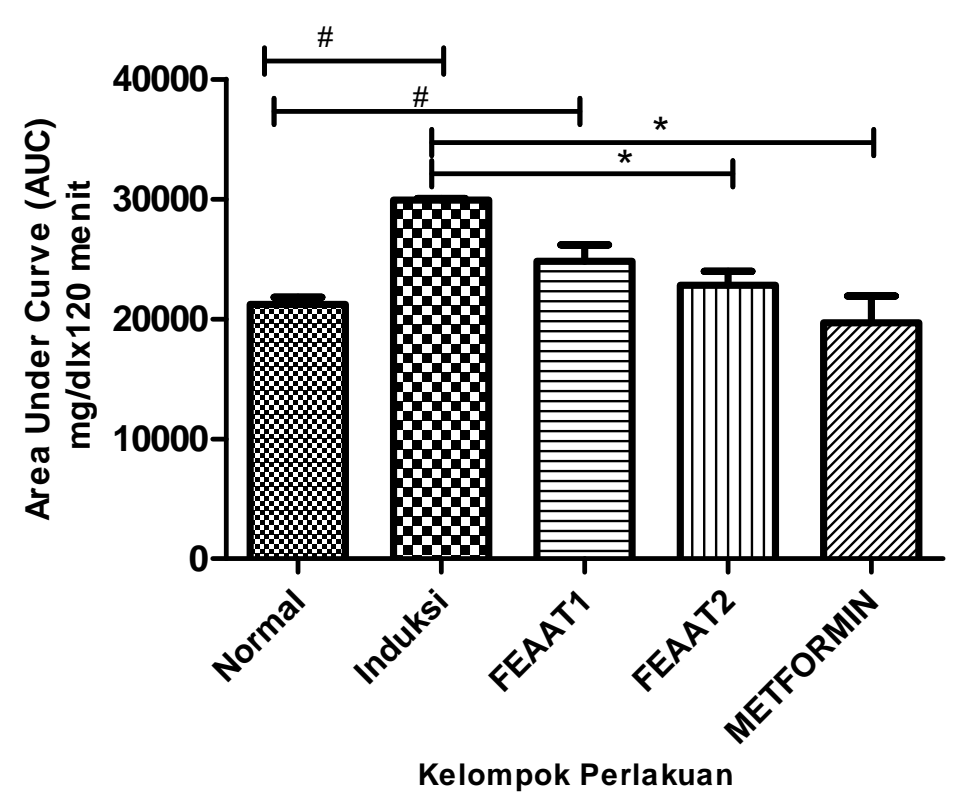

Gambar 2. Nilai rata-rata Area Under Curve $(A \cup C)$ kadar glukosa darah tiap perlakuan terhadap waktu.

$\left({ }^{*}\right) \mathrm{P}<0,05$ vs Induksi;, (\#) $\mathrm{P}<0,05$ vs Kontrol Normal

meningkatkan kadar kolesterol dengan cara menghambat sintesis hormon tiroid. Induksi dengan makanan tinggi lemak dan glukosa dapat menyebabkan pembesaran sel adiposit (Ai dkk, 2005).

Pengujian tes toleransi glukosa oral (TTGO) diawali dengan pengukuran KGD $\left(T_{0}\right)$ dan kemudian diberikan sediaan uji. Pemberian glukosa ( $2 \mathrm{~g} / \mathrm{kgbb})$ dilakukan 30 menit setelah pemberian sediaan uji. Selanjutnya dilakukan pengukuran glukosa darah setiap 30 menit dan dilakukan hingga 2 jam. Pemberian sediaan uji dilakukan 30 menit sebelum pemberian glukosa dimaksudkan untuk mengoptimalisasi penyerapan sediaan uji. Pengukuran glukosa hanya dilakukan dalam rentang waktu 2,5 jam karena KGD dapat kembali normal dalam waktu 2-2,5 jam setelah pemberian glukosa. AUC digunakan sebagai gambaran efek hipoglikemik dari fraksi etil asetat ampas tahu (FEAAT). Semakin kecil nilai AUC maka efek hipoglikemik semakin besar. Data AUC dapat dilihat pada Gambar 2.

Hasil pengujian efek yang ditunjukkan pada Gambar 2 menyatakan bahwa Nilai AUC pada FEAAT1 lebih kecil dibandingkan induksi. Akan tetapi secara statistik nilainya tidak signifikan. ( $P$ value $>0,05$ ). Sedangkan AUC FEAAT2 dan Metformin memiliki pengaruh yang berbeda nyata terhadap kelompok induksi ( $P$ Value $<0,05)$. Hal ini membuktikan bahwa pemberian FEAAT1 selama dua minggu belum menunjukkan efektivitasnya dalam menurunkan kadar glukosa darah, berbeda halnya dengan FEAAT2 dan Metformin yang sudah menunjukkan efektivitasnya menurunkan kadar glukosa darah pada model hewan resisten insulin. Jika dibandingkan dengan kelompok normal, nilai AUC kelompok FEAAT2 dan Metformin tidak mengalami perbedaan yang nyata ( $P$ value $>0,05)$, sehingga dikatakan bahwa pemberian FEAAT2 dan metformin selama dua minggu memberikan efek penurunan kadar glukosa darah yang sebanding dengan kelompok normal.

Jannatun (2009) melaporkan bahwa ampas tahu masih memiliki kandungan isoflavon genistein dan daidzein sebesar $65.93 \mathrm{mg} / 100 \mathrm{~g}$ dan $63.68 \mathrm{mg} / 100 \mathrm{~g}$. Kandungan ini diduga memiliki peranan dalam regulasi glukosa darah. Dalam penelitian Mezel (2003) dilaporkan bahwa Isoflavon dalam kedelai dapat mengaktifkan reseptor nuklir termasuk reseptor teraktivasi peroksisom-proliferator (PPAR) $\alpha$, PPAR $\gamma$, protein pengikat elemen yang diatur sterol, dan reseptor pengikat hati untuk mengatur metabolisme lemak dan glukosa. Isoflavon juga telah terbukti memperbaiki kondisi hiperglikemia, meningkatkan glukosa toleransi, dan meningkatkan konsentrasi insulin yang tersirkulasi (Babu et al. 2013), menstimulasi fosforilasi protein kinase teraktivasi-AMP dan asetil-KoA karboksilase untuk meningkatkan penyerapan glukosa dan oksidasi asam lemak (Cederroth et al. 2008). Menurut Kwon et al. (2010) isoflavon diduga memiliki efek sebagai antidiabetes melalui perantara reseptor estrogen. Reseptor estrogen $\alpha$ muncul sebagai molekul kunci yang terlibat dalam metabolisme glukosa dan lipid. Isoflavon adalah 
fitoestrogen yang secara alami terjadi dengan protein kedelai secara struktural dan fungsional mirip dengan estradiol (Kwon et al.,2010).

\section{SIMPULAN}

Fraksi etil asetat ampas tahu memiliki efek menurunkan kadar glukosa darah pada model hewan resisten insulin. Efektivitas ini baru terlihat pada pemberian fraksi etil asetat dosis $400 \mathrm{mg} / \mathrm{kg}$ bb selama 2 minggu.

\section{UCAPAN TERIMAKASIH}

Penulis mengucapkan terima kasih sebanyakbanyaknya kepada KEMENRISTEK DIKTI dan LPPM Universitas Pakuan yang telah memberikan telah memberikan fasilitas Hibah Penelitian Dosen Muda yang diberikan kepada penulis.

\section{DAFTAR PUSTAKA}

Ai, J., Wang, N., Yang, M., Du, Z.M., Zhang, Y.C., dan Yang, B.F. 2005. Develompment of Wistar Rat Model of Insulin Resistance. World J Gastroenteral. 11(24), 3675-3679.

American Diabetes Association (ADA). 2012. Standard of medical care in Diabetes. Diabetes care. Volume 35 , supplement 1.

Arbaiyah, Ita. 2003. Kandungan Protein dan Kalsium serta Daya Terima Susu Kedelai yang dibuat dari Ampas Tahu dengan Penambahan Bahan Pengental [Skripsi]. Medan (ID). Universitas Sumatera Utara.

Babu PV, Liu D, Gilbert ER. 2013. Recent advances in understanding the anti-diabetic actions of dietary flavonoids. J Nutr Biochem.; 24(11):1777-89.

BPS. 2012. Produksi Jagung, Padi dan Kedelai Badan Pusat Statistik (BPS), 2012. Produksi Padi, Jagung, dan Kedelai. (Angka Tetap 2011 Dan Angka Ramalan I 2012). Badan Pusat Statistik. No. 43/07/Th. XV, 2 Juli 2012 diakses pada 24 Agustus 2018

Cederroth CR, Vinciguerra $M$, Gjinovci A, Kühne F, Klein $M$, Cederroth $M$, Caille $D$, Suter $M$, Neumann $D$, James RW, Doerge DR, Wallimann T, Meda P, Foti M, Rohner-Jeanrenaud F, Vassalli JD. 2008. Dietary phytoestrogens activate AMP-activated protein kinase with improvement in lipid and glucose metabolism. Diabetes.; 57(5):1176-85.
Depkes RI. 1995. Materia Medika Indonesia, Jilid VI. Jakarta (ID). Departemen Kesehatan Republik Indonesia.

Depkes RI. 2000. Parameter Standar Umum Ekstrak Tumbuhan Obat. Jakarta: Direktorat Jendral Pengawasan Obat dan Makanan.

Derosa G, Maffioli P. 2010. Effects of thiazolidinediones and sulfonylureas in patients with diabetes. Diabetes Technol Ther. 12:491-501.

DiPiro, J.T., Talbert, R. L., Yee, G.C., Matzke, G. R., Wells, B.G., \& Posey, L.M. 2008. Pharmacotherapy: A Pathophysiologic Approach (7th Edition). USA: McGraw-Hill

Harborne, J.B. 1987. Metode Fitokimia Penuntun Cara Modern Menganalisa Tumbuhan. Bandung (ID): ITB.

Jannatun,R. 2009. Kadar Genistein Dan Daidzein Pada Kedelai, Ampas Tahu, Dan Oncom Merah (Skripsi). Bogor (ID): Insitut Pertanian Bogor.

Kwon, D. Y., Daily, J. W., Kim, H. J., \& Park, S. 2010. Antidiabetic effects of fermented soybean products on type 2 diabetes. Nutrition Research, $=$. 30(1), 113. doi:10.1016/j.nutres.2009.11.004 url to share this paper:sci-hub.se/10.1016/j.nutres.2009.11.004

Lorber D. 2014. Importance of cardiovascular disease risk management in patients with type 2 diabetes mellitus. Diabetes Metab Syndr Obes. 7:169-83. doi: 10.2147/DMSO.S61438

Reed MJ, Meszaros K, Entes LJ, Claypool MD, Pinkett JG, Gadbois TM, et al. 2000 A new rat model of type 2 diabetes: the fat-fed, streptozotocin-treated rat. Metabolism 49:1390-4. doi: 10.1053/meta.2000.17721

Srinivasan K, Viswanad B, Asrat L, Kaul CL, Ramarao P. 2005. Combination of high-fat diet-fed and low-dose streptozotocin-treated rat: a model for type 2 diabetes and pharmacological screening. Pharmacol Res. 523:313-20. doi: 10.1016/j.phrs.2005.05.004.

Sulistiani. 2004. Pemanfaatan Ampas Tahu dalam Pembuatan Pangan Tinggi Serat dan Protein sebagai Alternatif Bahan Baku Pangan Fungsional [Skripsi]. Bogor (ID). Fateta IPB.

Zimmet PZ, Magliano DJ, Herman WH, Shaw JE. 2014. Diabetes: a 21st century challenge. Lancet Diabetes Endo. 2:56-64. doi: 10.1016/S2213-8587(13)701128 